\title{
Kuujjua River Arctic Char: Monitoring Stock Trends Using Catches from an Under-Ice Subsistence Fishery, Victoria Island, Northwest Territories, Canada, 1991-2009
}

\author{
LOIS A. HARWOOD, ${ }^{1}$ STEPHEN J. SANDSTROM,${ }^{2}$ MICHAEL H. PAPST ${ }^{3}$ and HUMFREY MELLING ${ }^{4}$
}

(Received 7 May 2012; accepted in revised form 21 December 2012)

\begin{abstract}
A standardized, harvest-based monitoring program was conducted during the main under-ice subsistence fishery for Arctic char (Salvelinus alpinus) of the Kuujjua River for 18 winter fishing seasons between 1991 and 2009 . The program was a response to the concern of Ulukhaktok residents that Arctic char were becoming fewer in number and smaller in size. Mean harvests averaged 1225 (SD 262) Arctic char annually for 1996-2002 and 568 (SD 274) in 2003-09, or roughly 40\% and $20 \%$ of the harvest levels estimated for 1971-78 (2900, SD 842) and 1988-92 (2943, SD 1072). There was no statistical relationship between the size of the annual harvest (number of fish), and the corresponding mean annual catch per unit effort (CPUE) value $\left(\mathrm{R}^{2}=0.0141, p=0.761\right)$. Arctic char were fully recruited to the fishery at age nine, with $82.4 \%$ of the sampled catch $(\mathrm{n}=3288)$ ranging between 8 and 12 years and composed almost exclusively $(99 \%)$ of non-spawning adults. Over the time series, temporal trends were not detected $(p>0.05)$ in mean annual CPUE (27.3 Arctic char/100 m/24 h, SD 14.15), mean fork length (593 mm, SD 78.1), or mean age (9.9 years, SD 2.0). Annual mortality rate showed a weak, but significant, decreasing trend over the series $\left(\mathrm{R}^{2}=0.354\right)$, and there were no statistical trends in annual values of the Brody growth coefficient $\left(\mathrm{R}^{2}=\right.$ $0.1337, p=0.164)$. Variation in mean annual somatic condition indices was correlated with timing of sea ice clearance in spring $\left(\mathrm{R}^{2}=0.474, p=0.002\right)$, probably because prey quality, quantity, or both are higher in summers following earlier spring blooms in the marine environment. Together, the absence of temporal trends in CPUE, fork length, and age of the harvested fish and the apparent improvement in survival (lower mortality), suggest that the stock has been stable at the harvest levels observed during the monitoring period. The stock may also be realizing some improved fitness, which is due to changes in environmental productivity and appears to be linked, at least in part, to the timing of spring breakup in eastern Amundsen Gulf.
\end{abstract}

Key words: subsistence fishery, Arctic char, growth, age, length, CPUE, recruitment, sea ice, spring clearance, breakup

RÉSUMÉ. Entre 1991 et 2009, pendant 18 saisons de pêche hivernale, un programme de surveillance standardisé axé sur les récoltes a été réalisé quant à la pêche de subsistance principale d'omble chevalier (Salvelinus alpinus) sur la rivière Kuujjua. Ce programme a été mis en œuvre à la lumière des inquiétudes exprimées par les résidents d'Ulukhaktok qui affirmaient que le nombre d'ombles chevaliers diminuait, tout comme leur taille. De 1996 à 2002, la récolte moyenne d'ombles chevaliers atteignait 1225 (SD 262) annuellement, tandis que de 2003 à 2009, la récolte moyenne annuelle s'élevait à 568 (SD de 274), soit environ $40 \%$ et $20 \%$ des récoltes évaluées pour les années 1971 à 1978 (2 900, SD de 842) et les années 1988 à 1992 (2943, SD de 1072). Il n'existait pas de lien statistique entre la taille de la récolte annuelle (le nombre de poissons) et la valeur de la capture par unité d'effort (CPUE) moyenne annuelle correspondante $\left(\mathrm{R}^{2}=0,0141, p=0,761\right)$. L'omble chevalier était pleinement recruté à la pêche à l'âge de neuf ans, avec $82,4 \%$ de la capture échantillonnée $(n=3288)$ variant entre huit et 12 ans, et composée presque exclusivement (99\%) d'adultes non encore reproducteurs. Au fil des séries, aucune tendance temporelle n'a été décelée $(p>0,05)$ sur le plan de la CPUE moyenne annuelle (27,3 ombles chevaliers/100 m/24 h, SD 14,15), de la longueur moyenne à la fourche $(593 \mathrm{~mm}$, SD 78,1) ou de l'âge moyen $(9,9$ ans, SD 2,0). Le taux de mortalité annuel indiquait une tendance à la baisse à la fois faible mais importante au cours des séries $\left(\mathrm{R}^{2}=0,354\right)$, et il n'y avait pas de tendances statistiques du point de vue des valeurs annuelles du coefficient de croissance de Brody $\left(\mathrm{R}^{2}=0,1337, p=0,164\right)$. Une corrélation a été établie entre l'écart des indices somatiques annuels moyens et le moment du dégagement de la glace de mer au printemps $\left(\mathrm{R}^{2}=0,474, p=0,002\right)$, probablement parce que la qualité ou la quantité de proies, ou les deux, est plus élevée au cours des étés qui suivent une prolifération printanière hâtive dans l'environnement marin. Ensemble, l'absence de tendances temporelles relatives à la CPUE, à la longueur à la fourche et à l'âge du poisson récolté et l'amélioration apparente de la survie (mortalité plus faible) suggèrent que le stock était stable aux niveaux de récolte observés pendant la période de surveillance. Par ailleurs, il se pourrait que le stock connaisse une valeur d'adaptation quelque peu améliorée, ce qui est attribuable aux changements caractérisant la productivité environnementale et semble lié, tout au moins en partie, au moment de la débâcle du

\footnotetext{
${ }^{1}$ Fisheries and Oceans, 3015204 50th Avenue, Yellowknife, Northwest Territories X1A 1E2, Canada; Lois.Harwood@dfo-mpo.gc.ca

2 Port Sydney, Ontario P0B 1L0, Canada

${ }^{3}$ Fisheries Joint Management Committee, Inuvik, Northwest Territories X0E 0T0, Canada; present address: 365 Elm St., Winnipeg, Manitoba R3M 3N6, Canada

${ }^{4}$ Fisheries and Oceans, Institute of Ocean Sciences, Sidney, British Columbia V8L 4B2, Canada

(C) Her Majesty the Queen in Right of Canada. Administered by the Arctic Institute of North America
} 
printemps dans l'est du golfe Amundsen.

Mots clés : pêche de subsistance, omble chevalier, croissance, âge, longueur, CPUE, recrutement, glace de mer, dégagement au printemps, débâcle

Traduit pour la revue Arctic par Nicole Giguère.

\section{INTRODUCTION}

Anadromous Arctic char (Salvelinus alpinus) spawn and overwinter in the Kuujjua River system on Victoria Island, Northwest Territories, Canada. Residents of Ulukhaktok (formerly known as Holman), Northwest Territories, rely heavily on Arctic char for subsistence (Lewis et al., 1989; Paylor et al., 1998; Joint Secretariat, 2003). The main source of winter Arctic char for 479 community residents (Northwest Territories Bureau of Statistics, 2010) originates from the Kuujjua River system $\left(71^{\circ} 16^{\prime} \mathrm{N}, 116^{\circ} 49^{\prime} \mathrm{W}\right)$, which flows into Minto Inlet (Fig. 1) approximately $80 \mathrm{~km}$ from Ulukhaktok.
With headwaters $240 \mathrm{~km}$ to the east (Fig. 1), the river is navigable for only the first $3 \mathrm{~km}$ from the sea, after which it becomes shallow, with numerous rapids and boulder fields (Lewis et al., 1989). At $16 \mathrm{~km}$ from the mouth, the river flows from Tatik Lake (4200 hectares), known locally as "Fish Lake" and the primary spawning and overwintering site of Kuujjua River Arctic char. The extent to which Arctic char migrate upstream of Tatik Lake and use the other two lakes in the system is not known (Lewis et al., 1989), although local opinion indicates use of the upstream lakes is minimal (H. Wright, pers. comm. 1998) and possibly restricted by a waterfall between Second Lake and Third Lake (Fig. 1).

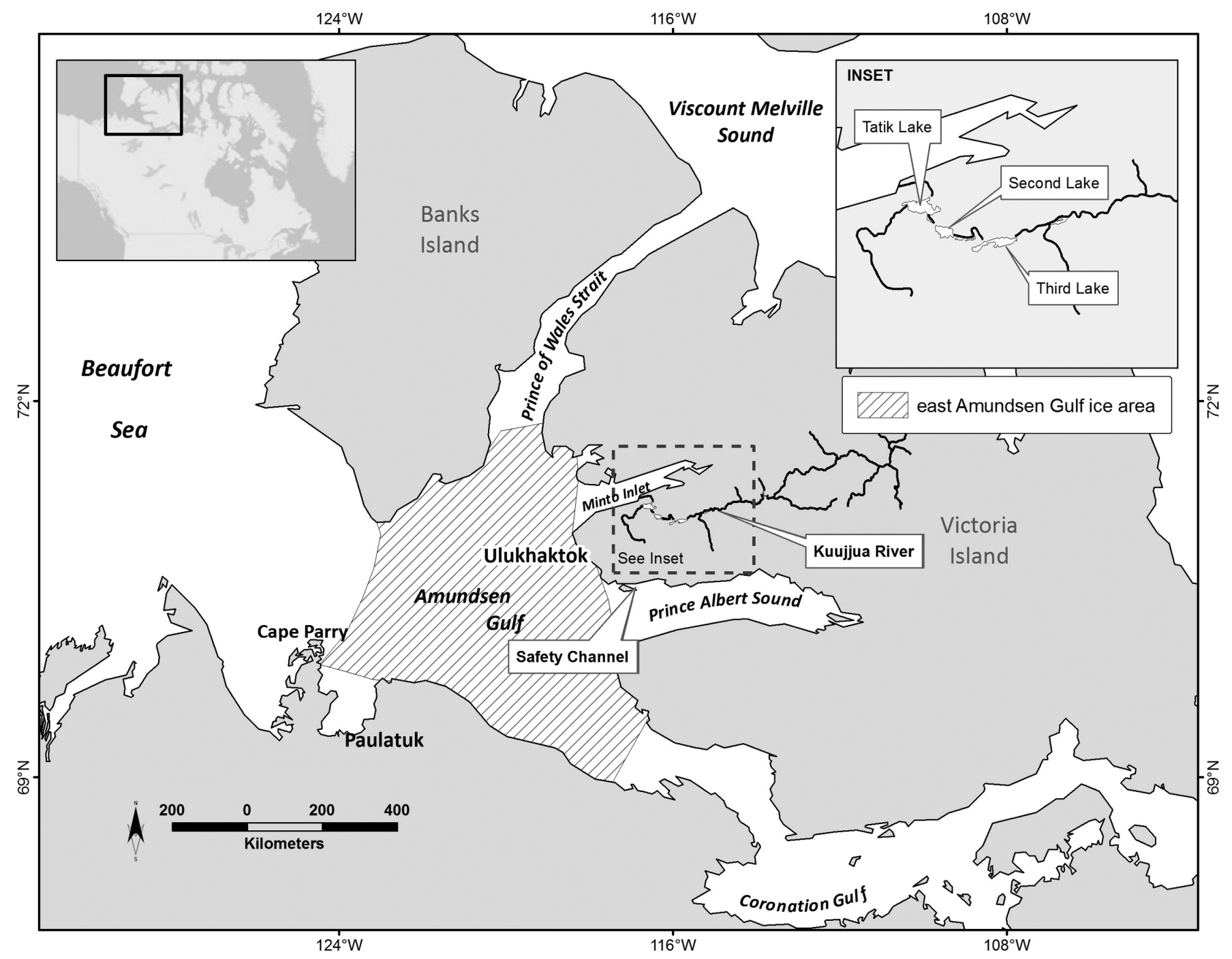

FIG. 1. Kuujjua River, Tatik Lake, and boundary of our eastern Amundsen Gulf ice area (adapted from Tivy et al., 2001). 
Arctic char remain throughout the winter in the freshwater lake(s), where they feed little or not at all (Johnson, 1980). Like other sea run Arctic char populations throughout the Arctic (Johnson, 1980; Dempson and Kristofferson, 1987), current-year non-spawning fish migrate downstream to the ocean in late spring to take advantage of the rich marine food resources. The migration takes place as soon as ice in the river breaks up sufficiently, and for the Kuujjua stock, this usually occurs during the third and fourth weeks of June (Lewis et al., 1989; D. Dowler, pers. comm. 1992; Paul Sparling, pers. comm. 1992). Kuujjua Arctic char likely spend approximately two months feeding in the coastal waters, which is typical of the species (Dempson and Kristofferson, 1987). Summer feeding ensures that the Arctic char increase their body condition in preparation for the upcoming overwintering period, when they do not feed (Johnson, 1980; Boivin and Power, 1990; Gyselman, 1994). Tagging results indicate that Kuujjua Arctic char range as far east as Safety Channel during summer, but they have not been documented to migrate beyond this point (Fig. 1; Lewis et al., 1989; DFO, unpubl. data).

Current year spawners generally remain in fresh water during the summer preceding spawning, and these have been documented in other populations to comprise only $2-7 \%$ of the population (Johnson, 1980). Victoria Island Arctic char have been observed to spawn every second or third year (Johnson, 1980; Dutil, 1986), usually during the month of September, and they are rarely caught in the Tatik Lake under-ice fishery because of its timing and location (Paylor et al., 1998).

The under-ice subsistence (or winter) fishery takes place at Tatik Lake from mid-October to early November each year. Since tag returns have shown that Arctic char caught in this fishery belong to the Kuujjua River stock, Tatik Lake is the most appropriate location for collecting stockspecific biological information, because the fish are not mixed with other stocks at that time. Tagged Kuujjua fish have been caught only in Tatik Lake and along the coast in summer (see below), and have not been caught during winter in other systems (HCWG, 2004; DFO, unpubl. data). Similarly, Arctic char tagged in the four largest, closest river systems (Kuuk, Kagluk, Kagloryuak, and Naloagyok) have never been caught in Tatik Lake during the annual winter fisheries (Baker, 1986; Stewart and Sparling, 1987; Sparling and Stewart, 1988; Lemieux and Sparling, 1990; HCWG, 2004). Kuujjua River Arctic char are caught in a mixed coastal fishery in summer, along with Arctic char from the above four rivers, particularly from the Kuuk. The size of the contribution of Kuujjua Arctic char to the summer marine fishery is not known, but it is likely less than 1000 fish annually (HCWG, 2004).

In response to community concerns raised in 1990 that Kuujjua River Arctic char were becoming fewer in number and smaller in size, the Fisheries Joint Management Committee initiated a harvest-based monitoring program at Tatik Lake in 1991 to monitor trends in fishing effort, catch rate, and biological attributes of Arctic char taken in the fishery. This harvest-based approach to collecting information required for management of the stock is practical for remote subsistence fisheries such as this, as it would be difficult and likely cost-prohibitive to use conventional, independent (from the fishery) methods of stock assessment (Gallagher and Dick, 2010; Roux et al., 2011).

This paper reports on the results of data collected by the harvest-based monitoring program from 1991 to 2009 (with the exception of 1993 when no fishery and no sampling took place). We explore whether temporal trends in fishing effort and biological attributes are discernable over the time period.

In addition, given the length of the time series and the timing of the fishery (relatively soon after Arctic char return from summer feeding), it was possible to explore the influence of the timing of sea ice clearance on the fitness of returning fish. The timing of ice clearance in spring reflects prevailing oceanographic and atmospheric conditions, and collectively, these conditions influence the strength and persistence of the marine spring bloom (Wu et al., 2007; Brown and Belt, 2012). Early clearance of sea ice promotes the growth of pelagic plankton communities, which in Amundsen Gulf in 2008 showed an 80\% increase in primary production compared with the average ice year in 2004 (review in Barber et al., 2008; Forest et al., 2011; Sallon et al., 2011). Here we examine whether this increase in pelagic plankton in turn influences higher trophic levels, in this case Arctic char from the Kuujjua River. Our hypothesis is that Arctic char would exhibit improved condition (unit body mass per unit body weight) in years when marine productivity is bolstered by earlier clearance of the sea ice in spring.

\section{METHODS}

The standardized, harvest-based monitoring program conducted from 1991 through 2009 included over 15000 hours of catch-per-unit-effort (CPUE) data and biological data from more than 3000 dead-sampled Arctic char over 18 winter fishing seasons. Monitors selected by the Olokhaktomiut Hunters and Trappers Committee worked during the peak three weeks of the under-ice Arctic char fishery at Tatik Lake, usually starting in the second week of October. The monitors sampled 200 fish from their own catches, which were included in the community's recommended take, and then distributed these fish to community elders. In addition, monitors visited camps of nearby fishers to obtain information on their catch success or specifically CPUE. Monitoring in 2006 deviated slightly, including a partial monitor sample during the October community fishery and then a second trip after the fishery, in late November, to obtain the remaining portion of the biological sample.

Holes were drilled in the ice with hand-held augers, and monofilament subsistence gillnets $20-50 \mathrm{~m}$ in length, with mesh sizes of either $102 \mathrm{~mm}, 114 \mathrm{~mm}$, and $127 \mathrm{~mm}$ 
stretched mesh (4", 4.5," and 5.0", respectively), were set under the ice, typically for 24 hours before being checked. Monitors maintained records of total number of Arctic char caught in the fishery, the length, mesh size, location, duration, and number of nets that were set, and the fork length $(\mathrm{mm})$, round weight $(\mathrm{g})$, and in 2000 and 2005-09, the sex of fish sampled. Monitors also noted if the fish were current-year spawners on the basis of testes or egg size, and external colouration. Sagittal otoliths were collected from all Arctic char in the monitoring sample for ageing and stored in labeled scale envelopes. All fish collected from the winter fishery were aged by the same individual using the whole otolith method described by Nordeng (1961).

In addition to the sample processed on site by the monitors, every third fish caught in the subsistence nets during 1991-2000, up to a total sample of 30 each year (305 in total for the time series), was frozen and shipped whole to the Fisheries and Oceans laboratories in Winnipeg, Manitoba. A similar level of information was collected in the lab from these fish, and in addition, gonad weight $(\mathrm{g})$ was measured and used to determine the gonadosomatic index (GSI), calculated as gonad weight/round weight $\times 100$.

Statistical analyses were conducted using Excel XLStatTIME, and SAS Version 8.0 on a PC (SAS, 1990). Significance level for all statistical tests was set at $5 \%$, unless otherwise stated.

CPUE was calculated as the number of Arctic char caught per $100 \mathrm{~m}$ of net fished for 24 hours. Annual means were compared using a Duncan's multiple range test in PROC GLM (General Linear Model) to evaluate the influence of mesh sizes on CPUE, and temporal trends were evaluated using a two-tailed Mann-Kendall trend test.

Temporal trends in mean fork length and mean age were similarly examined using box-whisker plots and MannKendall trend tests, for the entire series and for two intervals (1992-2002 and 2003-09) within the series. Somatic condition (K), a measure of the relative robustness of the fish (fitness), was determined as follows (Anderson and Gutreuter, 1983):

$$
\mathrm{K}=\mathrm{W} \times 10^{5} / \mathrm{L}^{3},
$$

where $\mathrm{W}=$ round weight in $\mathrm{g}$ and $\mathrm{L}=$ fork length in $\mathrm{mm}$.

Fishery Analyses and Simulation Tools (FAST 3.0) software (Slipke and Maceina, 2000) was used to fit, using non-linear least squares regression, the modified von Bertalanffy growth equation (Beverton and Holt, 1957) to the average fork length-at-age for each year of study:

$$
L_{t}=L_{\infty}\left(1-e^{-k\left(t-t_{o}\right)}\right)
$$

where $L_{t}$ is average length at age $t, L_{\infty}$ is asymptotic average length, $k$ is the Brody growth coefficient, and $t_{0}$ is the year when length is zero (modeling artifact).

The absence of juvenile age classes in the sample precluded generation of realistic estimates for $t_{0}$ as the plot of primarily older fish captured by the fishery was insufficient to accurately represent the curve in the earlier (younger) portion of the curve. To anchor the left-hand portion of the curve, $t_{0}$ was arbitrarily set at zero for all sample years.

Annual values for the Brody growth coefficient $k$ (i.e., the measure of exponential rate of approach to the asymptotic size, with larger $k$ values indicating a faster growth rate) were calculated by fixing $L_{\infty}$ at the time series average value (680 $\mathrm{mm}$ fork length). This was done after first establishing that $L_{\infty}$ was not significantly different throughout the time series (ANOVA, $p=0.4568$ ). The strength of the trend in $k$ was assessed using a Pearson correlation coefficient.

Annual mortality rates were obtained for each survey year using the standing age structure (i.e., all cohorts combined). This approach assumes that the level of recruitment to the fishery and mortality between years and between cohorts is similar (or random) and vulnerability to the fishery is equal. Given the length of the time series, it was also possible to calculate annual mortality from several individual cohorts sampled by the fishery over their lifespan, an approach that is free from the assumption of constant recruitment, but also has a similar caveat regarding consistency of mortality. Only those particular cohorts observed entering the fishery several years prior to full recruitment, and which were susceptible to the fishery for their entire lifespan to theoretical maximum age, were used in this calculation (cohort years 1985 to 1992). The extent of the observed catch-at-age deviation about the fitted catch curve typically represents variation in level of recruitment to the population, with higher $\mathrm{R}^{2}$ values indicating more consistent recruitment. Correlation coefficients for both approaches were compared using a t-test to evaluate the assumption of constant recruitment for the longer standing age structure mortality estimates.

Estimates of standing stock survival rate $(S)$ for each year of survey were derived using the catch curve method of Robson and Chapman (1961):

$$
\begin{gathered}
S=\frac{T}{\sum^{N+(T-1)}} \\
T=\sum_{x=0}^{k} x\left(N_{x}\right)
\end{gathered}
$$

where $N=$ number of fish (for ages fully recruited to gear), $x$ = coded age $(0,1,2 \ldots)$, where $\mathrm{N}_{0}$ is first age fully recruited to gear. Annual mortality (A) was thus calculated as $\mathrm{A}=$ $1-\mathrm{S}$. Trend in annual mortality for the time series was examined using a two-tailed Mann-Kendall trend test.

Annual timing of sea ice clearance (spring breakup) for eastern Amundsen Gulf (Fig. 1) was determined from navigational ice charts prepared weekly by the Canadian Ice Service for the last four decades (http://ice-glaces.ec.gc. ca). Eastern Amundsen Gulf was the focus for this analysis because tag returns indicate this to be the main summer coastal feeding habitat used by anadromous Arctic char from the Kuujjua River system (Lewis et al., 1989; DFO, unpubl. data). Sea ice clearance was defined as the earliest date when a flaw lead, or largely ice-free area, was 


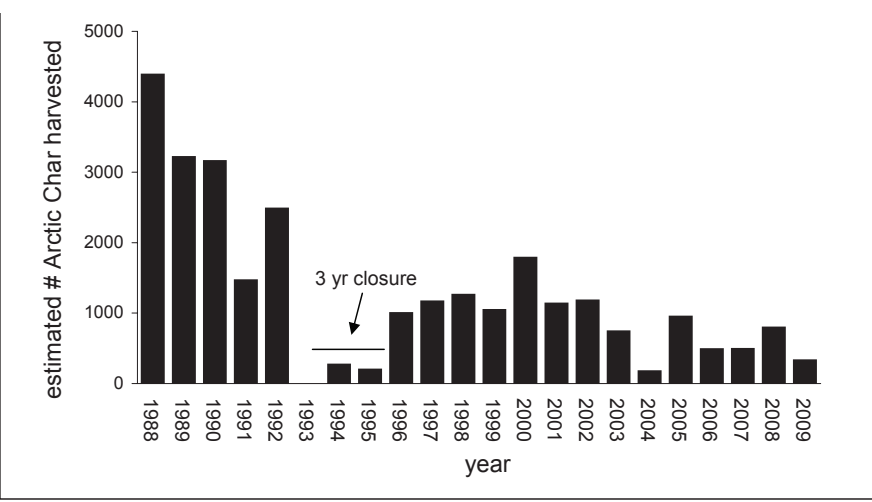

FIG. 2. Estimated harvests of Arctic char from Tatik Lake, 1988-2002 (Joint Secretariat, 2003; HCWG, 2004), 2003-04 (DFO, unpubl. data), and 2005-09 (this study).

charted across the mouth and seaward of Minto Inlet. The relationship between the mean annual somatic condition of returning Arctic char and the ice clearance date in the corresponding year was evaluated using least squares linear regression.

\section{RESULTS}

Prior to the time period of this study, the under-ice subsistence harvest of Arctic char at Tatik Lake averaged 2900 (SD 842) fish in 1991-78 (Lewis et al., 1989), and 2943 (SD 1072) fish in 1988-92 (Joint Secretariat, 2003; DFO, unpubl. data). After the 1993-95 fishery closure, the annual harvest averaged 1225 (SD 262) fish from 1996 to 2002, and 568 (SD 274) fish from 2003 to 2009 (Joint Secretariat, 2003; DFO, unpubl. data; this study, Fig. 2).

The timing of the fishery was reasonably consistent each year, with $90 \%$ of the sampled Arctic char being caught during the month of October (median between October 12 and November 1) (Fig. 3). The sampling period was also consistent, averaging 13.6 days (range 5-19 days) of fishing effort (Fig. 3). Catch data were recorded for a total of 15844 h over 18 consecutive fishing seasons (except in 1993).

Most Arctic char were caught using $114 \mathrm{~mm}\left(4.5^{\prime \prime}\right)$ mesh nets $(88.8 \%)$, and the second most prevalent mesh size was $127 \mathrm{~mm}$ (5") (9.1\%) (Fig. 4). CPUE was not different across any of the mesh sizes used in the fishery $\left(\mathrm{F}=2.40, \mathrm{df}_{2,648}\right.$; $p>\mathrm{F}=0.0913)$, with mean CPUE for each mesh size falling in the same Duncan grouping $(p>0.05)$ (Table 1).

Annual CPUE ranged from a low of five Arctic char per $100 \mathrm{~m} / 24 \mathrm{~h}$ in 1991 to a high of 42 per $100 \mathrm{~m} / 24 \mathrm{~h}$ in

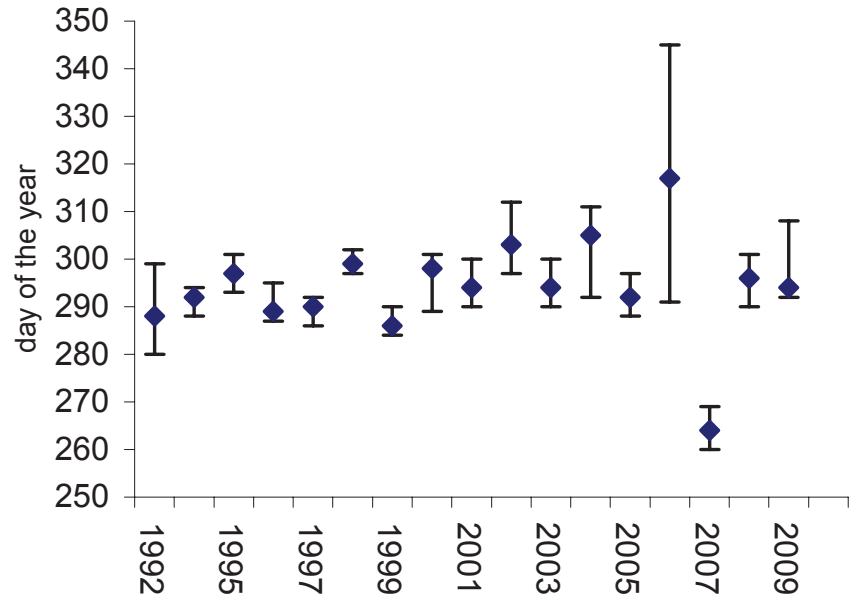

FIG. 3. Timing and duration for sampling of subsistence harvests at the Tatik Lake under-ice fishery, 1992-2009. Error bars represent the first and last Arctic char sampled from the fishery. Diamonds represent median number of fish caught.

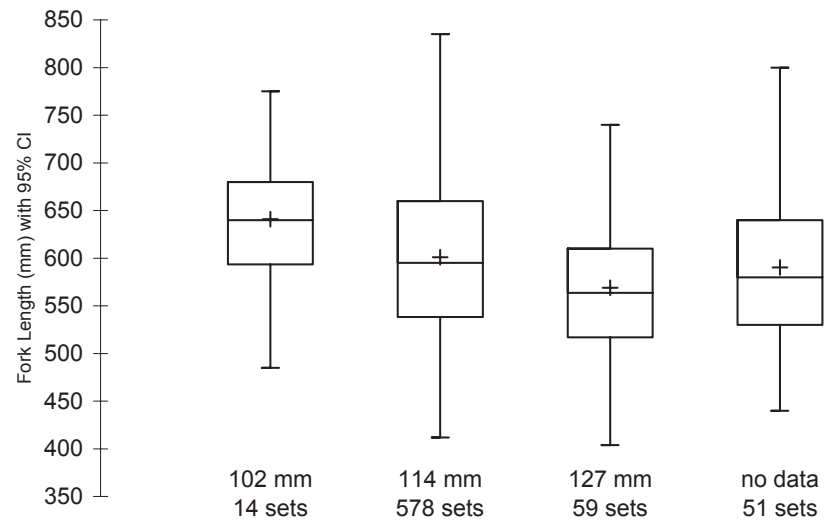

FIG. 4. Box-whisker plot of fork length of Arctic char caught in subsistence nets at Tatik Lake in $1992-2009$, by mesh size. Boxes $=75 \%$ of observations; $+=$ mean; $\_$median.

1996, with an overall series mean CPUE of 25.0 (SD 24.6). Catch data from 2009 were excluded from CPUE analyses due to incomplete catch records $(n=12)$. Annual CPUE values were variable (Fig. 5), but there was no trend toward increasing or decreasing CPUE over the time series ( $p=$ 0.490 ). We also did not detect a relationship between the size of the annual harvest (number of fish) and the corresponding mean annual CPUE value $\left(\mathrm{R}^{2}=0.0141, p=0.761\right)$ (Fig. 6).

In total, 3288 Arctic char were sampled from the underice subsistence fishery during 18 fishing seasons. Overall

TABLE 1. Mean fork length and CPUE, by mesh size, for the winter Arctic char subsistence fishery at Tatik Lake, $1992-2009$.

\begin{tabular}{|c|c|c|c|c|c|c|c|}
\hline \multicolumn{2}{|c|}{ Mesh size } & \multicolumn{3}{|c|}{ Fork length (mm) } & \multicolumn{3}{|c|}{ CPUE (no. char/100 m/24 h) } \\
\hline $\mathrm{mm}$ & in & mean & $\mathrm{SD}$ & $\mathrm{n}$ & mean & SD & No. of sets \\
\hline 102 & 4.0 & 640.9 & 70.5 & 62 & 15.2 & 14.7 & 14 \\
\hline 114 & 4.5 & 600.2 & 80.6 & 1858 & 27.5 & 26.0 & 578 \\
\hline 127 & 5.0 & 569.0 & 73.1 & 568 & 22.8 & 22.8 & 59 \\
\hline Total & & & & 2488 & & & 651 \\
\hline
\end{tabular}




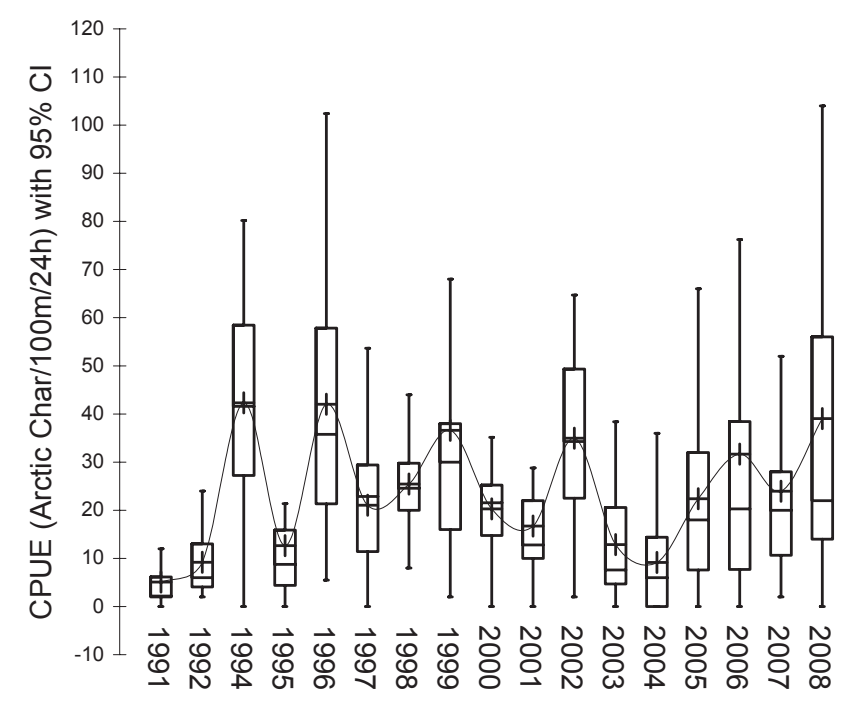

FIG. 5. CPUE for Arctic char caught at the Tatik Lake under-ice subsistence fishery, 1991-2008, by year. Symbols as in Figure 4.

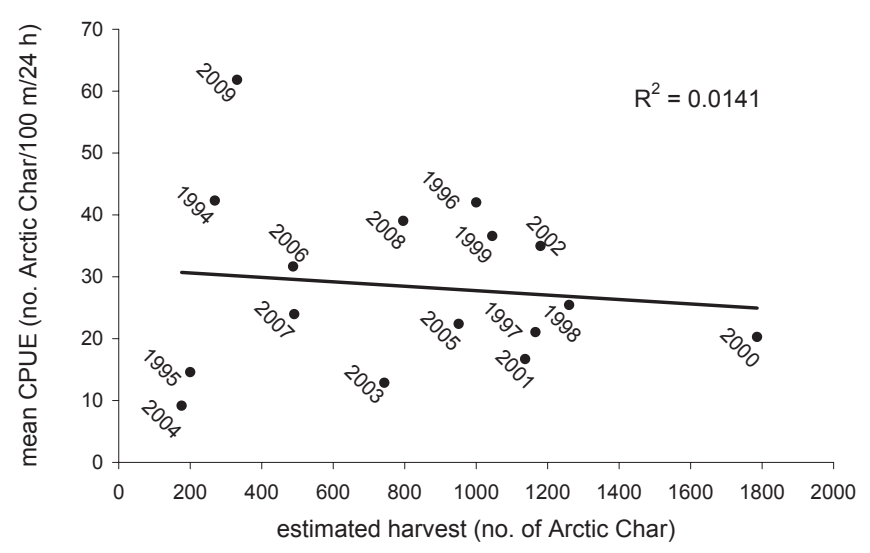

FIG. 6. Scatterplot of estimated annual harvest of Arctic char in the under-ice subsistence fishery at Tatik Lake and mean CPUE, 1992-2009.

mean fork length was $593 \mathrm{~mm}$ (SD 78.1, $\mathrm{n}=3288$; range $290-862 \mathrm{~mm}$ ), and mean round weight was $2560 \mathrm{~g}$ (SD $1079, \mathrm{n}=3232)$. There was a sustained period of increasing fork length $(p<0.0001)$ from 1992 to 2002, followed by a period of significantly decreasing fork length $(p=0.030)$ from 2003 to 2009 (Fig. 7). Age structure was stable during the former $(p=0.727)$ and declined during the latter, although not significantly so $(p=0.136)$. A closer examination of length and age frequency distributions for 2007-09 reveals that this decline was due to an increase in the prevalence of younger fish in the fishery (Fig. 8).

Similar sex ratios were observed in the monitor's field sample and in the frozen sample sent to the laboratory (lab $50.4 \%$ female, range $37-68 \%, \mathrm{n}=305$; monitor $52.4 \%$ female, range $35.5-74.6 \%, \mathrm{n}=1178$ ). Fewer than $1 \%$ of the Arctic char sampled by monitors between 2000 and 2009 were classified as ripe or spent fish in the year of capture (i.e., current-year spawners). In the laboratory, all 305 of the frozen whole fish were assessed as current year non-spawners. Minimum and maximum GSI values ranged from 0.02

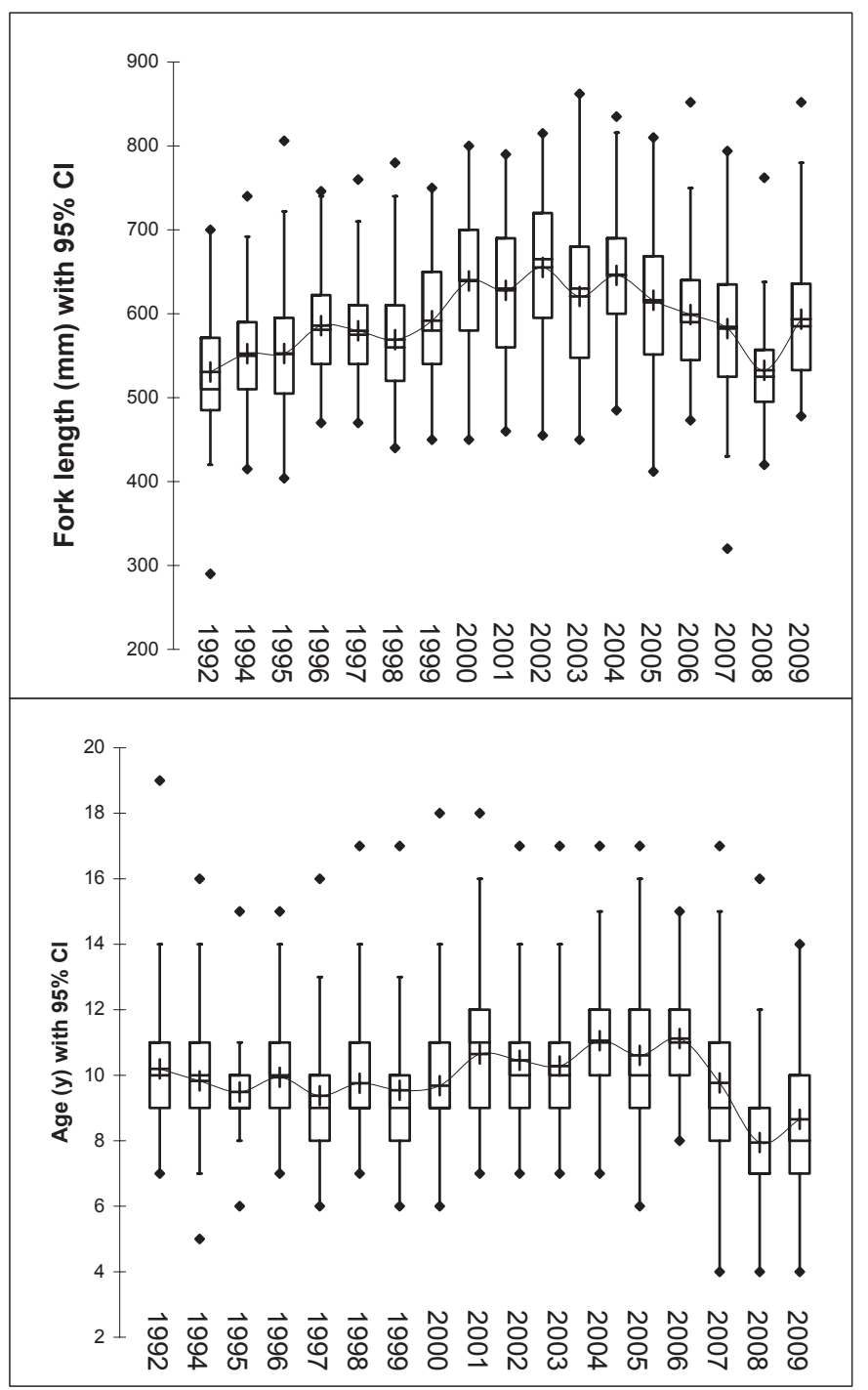

FIG. 7. Box-whisker plots for fork length and age of Arctic char sampled in the under-ice subsistence fishery at Tatik Lake in 1992 and 1994-2009. Symbols as in Figure 4.

to 1.69 for males (mean $0.086, \mathrm{n}=149$ ), and 0.10 to 5.05 for females (mean $0.53, \mathrm{n}=156$ ).

From a total of 3131 Arctic char that were aged, the youngest was 4 years old $(n=4)$, and the oldest $19(n=1)$. Mean age of harvested fish was 9.9 years (SD 2.0). Arctic char are fully recruited to this fishery at age 9 , with $82.4 \%$ of the catch being $8-12$ years of age. Fewer than $9 \%$ of the fish caught were observed to be older than 12 years.

Temporal linear correlation analysis of the Brody growth coefficient $(k)$ (i.e., length-at-age), from the fit of the von Bertanlaffy growth model for each year, did not reveal a significant trend in growth over the monitoring period (Pearson $\mathrm{R}^{2}=0.23 ; p=0.164$ ) (Fig. 9).

Correlation coefficients for both the weighted catch curve for individual cohorts (mean $\mathrm{R}^{2}=0.93$, CI 0.90 to 0.95 ) and the annual age structure of standing stock (mean $\mathrm{R}^{2}=0.93$; CI 0.91 to 0.95 ) were very high and did not differ statistically (t-test; $p=0.830$; variance equal), suggesting the assumption of constant recruitment for the longer 


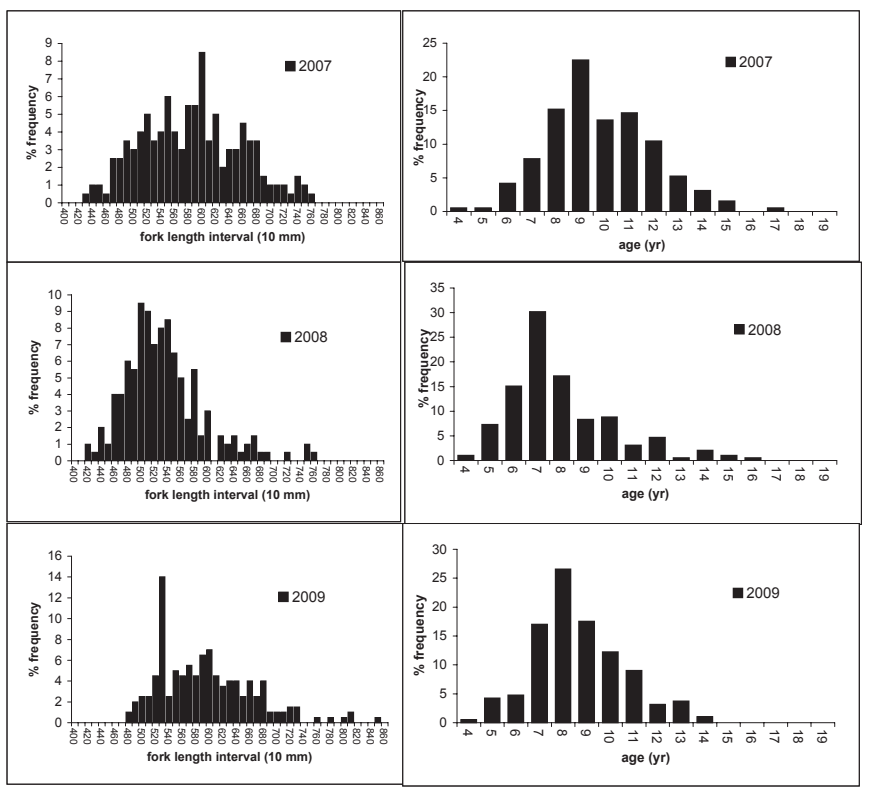

FIG. 8. Frequency distribution of fork length and age of Arctic char sampled from the subsistence fishery at Tatik Lake in 2007-09.

standing stock time series was not violated. We detected a declining temporal trend in annual mortality over the series $\left(\mathrm{F}=8.209, \mathrm{df}_{1,16} ; p=0.012 ; \mathrm{R}^{2}=0.354, p=0.032\right)$. Annual mortality estimates over the time series averaged 0.45 , with $95 \%$ CI of 0.42 to 0.48 (Fig. 10).

Examination of clearance date of the sea ice in eastern Amundsen Gulf in spring over the 40-year time record (1970-2011) found a trend toward earlier clearance of 7.4 days per decade, but this trend was significant only at the $90 \%$ level (Fig. 11). There was no trend detected toward later freeze-up date over the time series (Fig. 11). Mean and median ice clearing dates for the eastern Amundsen Gulf were 11 and 26 July, respectfully.

Timing of sea ice clearance in spring was significantly correlated with condition of returning Arctic char in the same year $\left(\mathrm{R}^{2}=0.466 ; p=0.002\right)$ (Fig. 12$)$, with early clearance years producing the fish with highest condition values.

\section{DISCUSSION}

Available harvest data from this monitoring program suggest that recent levels of harvest are only $20 \%$ to $40 \%$ of harvest levels in the 1970s and 1980s. The community's fishing plan (HCWG, 2004), with support from the Fisheries Joint Management Committee, appears to have been successful in reducing the annual level of harvest and fostering compliance by local subsistence fishers.

Excessive harvest pressure can affect the sustainability of fish stocks by altering the size and age structure of the population, growth rates, maturation schedules, and investment in reproduction (e.g., Gallagher and Dick, 2010; Roux et al., 2011). The primary goal of the monitoring program was to obtain a long-term record of life history information

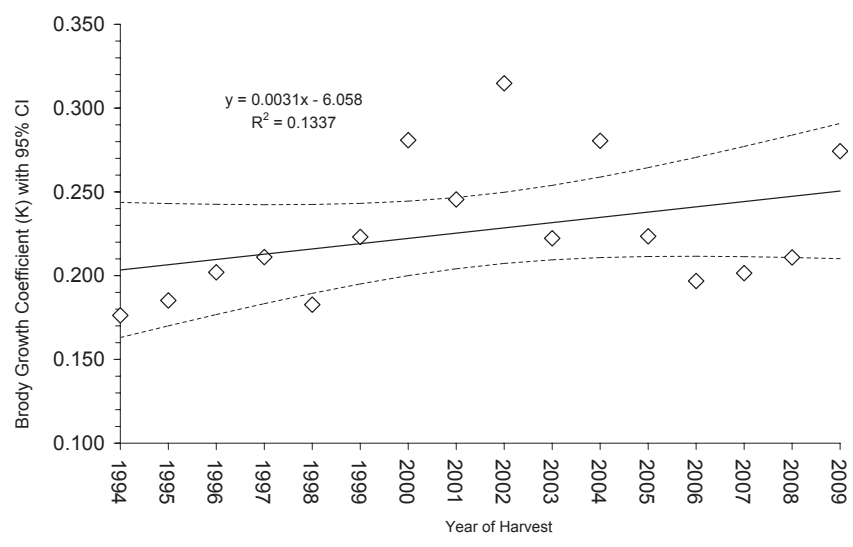

FIG. 9. Brody growth coefficients for Arctic char sampled at the under-ice subsistence fishery at Tatik Lake in 1994-2009, by year.

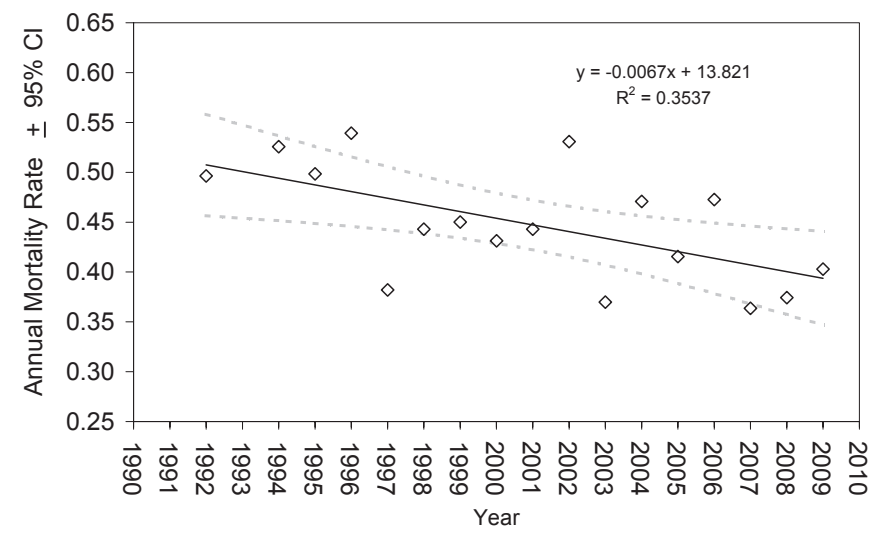

FIG. 10. Annual mortality rate of the annual harvest of Arctic char at the under-ice subsistence fishery in Tatik Lake, 1992 to 2009.

about this stock that could be used by co-management partners in making informed management decisions. Over the time series, the absence of temporal trends in CPUE, fork length, and age of the harvested fish, combined with apparent improvement in survival (lower mortality), suggests that the stock has been stable at the harvest levels observed during the monitoring period and may also be realizing some improved fitness that is due in part to changes in the marine environment.

It is probable that the location and timing of the fishery has, in some part, contributed to the stability of the stock by not routinely removing spawning individuals prior to spawning. GSI values that we obtained confirmed this to be the case, since they were similar to the mean GSI value of $1.2 \%$ reported by McCart (1980) for females in years between spawning.

The stock also appears to benefit from relatively stable and predictable spawning and early life history success, as indicated by the low variability in the catch curve correlation coefficients calculated by either the individual cohort or the whole standing stock approach. Together, these benefits increase the resilience of the population to fishing pressure. 


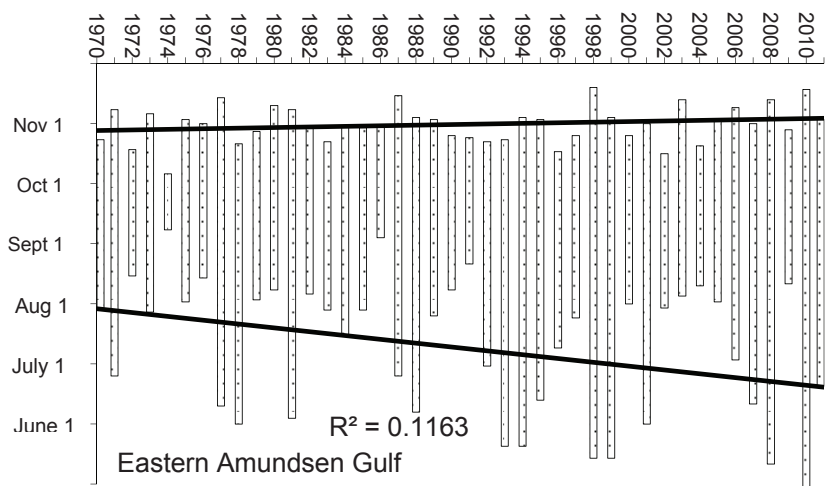

FIG. 11. Duration of ice-free season in eastern Amundsen Gulf, 1970-2011.

Trend tests did reveal a period of sustained, increasing fork length in the first half of the time series (Fig. 7, upper) and a corresponding stable age structure (Fig. 7, lower). This trend is likely the result of improved feeding opportunities, as reflected by the observed condition factor in the mid to late 1990s. In the latter half of the time series, there was a significant decrease in mean fork length and a concomitant (but not significant) decline in mean age. Again, a probable explanation is that the enhanced Arctic char growth and fitness in the late 1990s contributed to a pulse of recruitment that appeared as seven-, eight- and nineyear-olds in the fishery in 2007-09 (Fig. 8). This increase in seven- to nine-year-olds is a positive sign for the health of the stock, especially given that harvest levels were capped in 1992.

The pan-Arctic perspective has shown statistically significant trends toward thinner ice, earlier ice clearance, and longer ice-free seasons throughout much of the Arctic (Comiso and Parkinson, 2004; Serreze et al., 2007; Barber et al., 2008; Walsh, 2008). The trends in the Amundsen Gulf region, however, have been less pronounced than in other areas of the Arctic (Melling and Riedel, 2004; Melling et al., 2005), and Ulukhaktok was not included on a recent list of the most affected Arctic communities (Galley et al., 2012). Although observations over the last four decades have revealed large fluctuations in ice presence and thickness in Amundsen Gulf, the trend toward earlier ice clearance has so far been weak, at only $7.4 \mathrm{~d}$ per decade $(p=0.10)$.

Walsh (2008), Wu et al. (2007), Barber et al. (2008), and Sallon et al. (2011) report that primary production is enhanced when spring ice clearance is early. The opposite occurs when ice clearance is later in the season: reduced light levels and lower temperatures lead to later blooms and lower overall marine productivity (Forest et al., 2011). Although spring ice clearance date is only a crude measure of marine productivity, it does represent a suite of prevailing oceanographic and atmospheric conditions, including winds, currents, and air and water temperatures. While it does not reveal the location, quality, and quantity of available prey, ice clearance date appears to serve as an index of feeding conditions, both timing and opportunities.

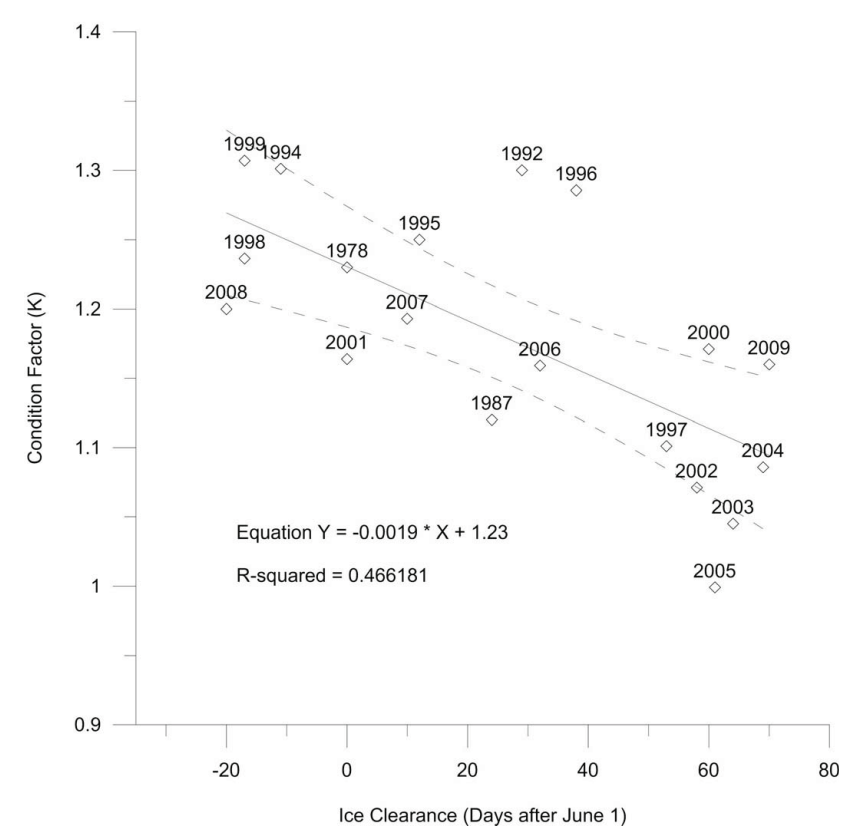

FIG. 12. Scatterplot of ice clearance date in eastern Amundsen Gulf and condition factor of Arctic char caught in the under-ice subsistence fishery at Tatik Lake in 1978 and 1987 (Lewis et al., 1989) and in 1992 and 1994-2009 (this study).

Results from our long-term monitoring program have revealed that stock fitness can be strongly influenced by variability and vagaries of the environment, in this case, the timing of spring breakup. Variation in Arctic char condition has been shown to be coupled with the timing of clearance of sea ice in spring: fish having significantly better condition in years with earlier ice clearance. The linkage between Arctic char condition and timing of sea ice clearance has been documented previously in other Salvelinus stocks over the same time period (e.g., Rat River Dolly Varden [Harwood et al., 2009]; Hornaday River char, [DFO, 2000; Harwood, 2009]). Observations made by community harvesters are also well matched with climate-related changes in the somatic condition of Arctic char (Knopp, 2010).

Our results point to the importance of long-term, consistent data sets for the monitoring of key Arctic char fisheries. Continued monitoring is important to identify trends in condition and life history traits to assess sustainability, and a harvest-based approach is an effective monitoring tool in cases such as this (Bell and Harwood, 2012). To the extent that it is practical and relevant to a specific fishing location or timing, we urge the inclusion of measurements of sea ice and other environmental variables, at appropriate spatial and temporal scales for species that use marine resources for summer feeding.

\section{ACKNOWLEDGEMENTS}

The work and dedication of the fishery monitors are gratefully acknowledged. In particular, we thank Buddy Alikamik, Morris Nigiyok, Isaac Inuktalik, Joseph Haluksit, John Alikamik, Harold 
Wright, and Walter Olifie. We apologize to anyone that we may have missed. We thank Lillian Kanayok, Bessie Inuktalik, and the late Wilma Memogana, all of the Olokhaktomiut Hunters and Trappers Committee, for assistance with program administration. The data could not have been collected without the support of the Olokhaktomiut HTC and the people of Ulukhaktok, who allowed their catches to be enumerated and sampled. All samples were aged by G. Carder, formerly of the Department of Fisheries and Oceans (DFO), and presently of Salmon Arm, British Columbia. Dr. A. Kristofferson (DFO) and the late Don Dowler (Vice-Chair, Fisheries Joint Management Committee) gave field advice and support over the years it took to collect the field data. We thank Robert K. Bell, Dr. Al Kristofferson, and two anonymous reviewers for helpful reviews of earlier versions of this manuscript. We gratefully acknowledge annual funding for this program provided by the Fisheries Joint Management Committee, Inuvik, Northwest Territories, established under the Inuvialuit Final Agreement.

\section{REFERENCES}

Anderson, R.O., and Gutreuter, S.J. 1983. Length, weight and associated structural indices. In: Nielsen, L.A., and Johnson, D.I., eds. Fisheries techniques. Bethesda, Maryland: American Fisheries Society. 283-300.

Baker, R.F. 1986. Report on the test fishery of the Kuuk River, Prince Albert Sound, Northwest Territories, 1986. Unpubl. report by North/South Consultants Inc., Winnipeg, Manitoba. Available at the Joint Secretariat, Box 2120, Inuvik, Northwest Territories X0E 0T0. $25 \mathrm{p}$.

Barber, D.G., Lukovich, J.V., Keogak, J., Baryluk, S., Fortier, L., and Henry, G.H.R. 2008. The changing climate of the Arctic. Arctic 61(Suppl. 1):7-26.

Bell, R.K., and Harwood, L.A. 2012. Harvest-based monitoring in the Inuvialuit Settlement Region: Steps for success. Arctic 65(4):421-432.

Beverton, R.J.H., and Holt, S.J. 1957. On the dynamics of exploited fish populations. Fisheries Investigations, Series 2, 19. United Kingdom: Ministry of Agriculture and Fisheries. 533 p.

Boivin, T.G., and Power, G. 1990. Winter condition and proximate composition of anadromous Arctic charr (Salvelinus alpinus) in eastern Ungava Bay, Quebec. Canadian Journal of Zoology 68(11):2284-2289.

Brown, T.A., and Belt, S.T. 2012. Closely linked sea ice-pelagic coupling in the Amundsen Gulf revealed by the sea ice diatom biomarker IP25. Journal of Plankton Research 34(8):647-654.

Comiso, J.C., and Parkinson, C.L. 2004. Satellite-observed changes in the Arctic. Physics Today 57(8):38-44.

Dempson, J.B., and Kristofferson, A.H. 1987. Spatial and temporal aspects of the ocean migration of anadromous Arctic char. In: Dadswell, M.J., Klauda, R.J., Moffitt, C.M., Saunders, R.L., Rulifson, R.A., and Cooper, J.E., eds. Common strategies of anadromous and catadromous fishes: Proceedings of an international symposium, 9-13 March 1986, Boston, Massachusetts. American Fisheries Society Symposium 1. $340-357$.
DFO (Department of Fisheries and Oceans). 2000. Hornaday River Arctic charr. DFO Science Stock Status Report D5-68 (1999).

Dutil, J.-D. 1986. Energetic constraints and spawning interval in the anadromous Arctic charr (Salvelinus alpinus). Copeia 4:945-955.

Forest, A., Tremblay, J.-É., Gratton, Y., Martin, J., Gagnon, J., Darnis, G., Sampei, M., et al. 2011. Biogenic carbon flows through the planktonic food web of the Amundsen Gulf (Arctic Ocean): A synthesis of field measurements and inverse modeling analyses. Progress in Oceanography 91:410-436, doi:10.1016/j.pocean.2011.05.002.

Gallagher, C.P., and Dick, T.A. 2010. Historical and current population characteristics and subsistence harvest of Arctic char from the Sylvia Grinnell River, Nunavut, Canada. North American Journal of Fisheries Management 30(1):126-141.

Galley, R.J., Else, B.G.T., Howell, S.E.L., Lukovich, J.V., and Barber, D.G. 2012. Landfast sea ice conditions in the Canadian Arctic: 1983-2009. Arctic 65(2):133-144.

Gyselman, E.C. 1994. Fidelity of anadromous Arctic char (Salvelinus alpinus) to Nauyuk Lake, N.W.T., Canada. Canadian Journal of Fisheries and Aquatic Sciences 51(9):1927-1934.

Harwood, L.A. 2009. Status of anadromous Arctic charr (Salvelinus alpinus) of the Hornaday River, Northwest Territories, as assessed through harvest-based sampling of the subsistence fishery, August-September 1990-2007. Canadian Manuscript Report of Fisheries and Aquatic Sciences 2890. Yellowknife: DFO, Central and Arctic Region. vii +34 p.

Harwood, L.A., Sandstrom, S., and Linn, E. 2009. Status of anadromous Dolly Varden (Salvelinus malma) of the Rat River, Northwest Territories, as assessed through sampling of the subsistence fishery (1995-2007). Canadian Manuscript Report of Fisheries and Aquatic Sciences 2891. Yellowknife: DFO, Central and Arctic Region. vii $+52 \mathrm{p}$.

HCWG (Holman Char Working Group). 2004. Holman char fishing plan 2004-2006. http://fishfp.sasktelwebhosting.com/ publications/Holman\%20char\%20Plan04_06.pdf.

Johnson, L. 1980. The Arctic charr, Salvelinus alpinus. In: Balon, E.K., ed. charrs: Salmonid fishes of the genus Salvelinus. The Hague, Netherlands: Junk. 15-98.

Joint Secretariat. 2003. The Inuvialuit Harvest Study: Data and methods report 1988-1997. Available at the Joint Secretariat, Box 2120, Inuvik, Northwest Territories X0E 0T0.

Knopp, J.A. 2010. Investigating the effects of environmental change on Arctic char (Salvelinus alpinus) growth using scientific and Inuit traditional knowledge. Arctic 63(4):493-497.

Lemieux, P.J., and Sparling, P.D. 1990. A biological assessment of Arctic charr in the Naloagyok River, Victoria Island, NWT. Prepared by Department of Fisheries and Oceans, Inuvik, NT. Available at the Joint Secretariat, Box 2120, Inuvik, Northwest Territories X0E 0T0.

Lewis, P.N.B., Kristofferson, A.H., and Dowler, D.H. 1989. Data from fisheries for Arctic charr, Kuujjua River and Holman areas, Victoria Island, Northwest Territories, 1966-87. Canadian Data Report of Fisheries and Aquatic Sciences 769. $17 \mathrm{p}$. 
McCart, P.J. 1980. A review of the systematics and ecology of Arctic char, Salvelinus alpinus, in the Western Arctic. Canadian Technical Report of Fisheries and Aquatic Sciences 935. $89 \mathrm{p}$.

Melling, H., and Riedel, D.A. 2004. Draft and movement of pack ice in the Beaufort Sea: A time-series presentation April 1990-August 1999. Canadian Technical Report of Hydrography and Ocean Sciences 238. Sidney, British Columbia: Institute of Ocean Sciences, Fisheries and Oceans. $\mathrm{v}+24 \mathrm{p}$.

Melling, H., Riedel, D.A., and Gedalof, Z. 2005. Trends in the draft and extent of seasonal pack ice, Canadian Beaufort Sea. Geophysical Research Letters 32, L24501, doi:10.1029/2005GL024483.

Nordeng, H. 1961. On the biology of char (Salmo alpinus L.) in Salangen, North Norway. 1. Age and spawning frequency determined from scales and otoliths. Nytt Magazine Zoology 10:67-123.

Northwest Territories Bureau of Statistics. 2010. Community data: Ulukhaktok. http://www.statsnwt.ca/community-data/ index.html.

Paylor, A.D., Papst, M.H., and Harwood, L.A. 1998. Community household surveys on the Holman subsistence Arctic charr (Salvelinus alpinus) fishery priorities, needs and traditions. Canadian Technical Report of Fisheries and Aquatic Sciences 2234. 16 p.

Robson, D.S., and Chapman, D.G. 1961. Catch curves and mortality rates. Transactions of the American Fisheries Society 90(2):181- 189.

Roux, M.J., Tallman, R.F., and Lewis, C.W. 2011. Small-scale Arctic charr Salvelinus alpinus fisheries in Canada's Nunavut: Management challenges and options. Journal of Fish Biology 79(6):1625-1647, doi:10.1111/j.1095-8649.2011.03092.x.
Sallon, A., Michel, C., and Gosselin, M. 2011. Summertime primary production and carbon export in the southeastern Beaufort Sea during the low ice year of 2008. Polar Biology 34:1989-2005, doi:10.1007/s00300-011-1055-5.

SAS (Statistical Analysis System). 1990. SAS Version 8.0. Cary, North Carolina: SAS Institute Inc.

Serreze, M.C., Holland, M.M., and Stroeve, J. 2007. Perspectives on the Arctic's shrinking sea-ice cover. Science 315(5818):1533- 1536.

Slipke, J.W., and Maceina, M.J. 2000. Fishery analyses and simulation tools (FAST), version 3.0. Auburn, Alabama: Auburn University.

Sparling, P.D., and Stewart, D.B. 1988. A biological assessment of Arctic charr in the Kagluk River, Victoria Island, NWT, 1988. Prepared by P. Sparling Consulting and Arctic Biological Consultants, Manitoba. Available at the Joint Secretariat, Box 2120, Inuvik, Northwest Territories X0E 0T0.

Stewart, D.B., and Sparling, P.D. 1987. A biological assessment of Arctic charr stocks in the Kuuk and Kagluk Rivers, Victoria Island, NWT, 1987. Prepared by Arctic Biological Consultants, Winnipeg, Manitoba. Available at the Joint Secretariat, Box 2120, Inuvik, Northwest Territories X0E 0T0.

Tivy, A., Howell, S.E.L., Alt, B., McCourt, S., Chagnon, R., Crocker, G., Carrieres, T., and Yackel, J.J. 2011. Trends and variability in summer sea ice cover in the Canadian Arctic based on the Canadian Ice Service Digital Archive, 1960-2008 and 1968-2008. Journal of Geophysical Research 116, C03007, doi:10.1029/2009JC005855.

Walsh, J.E. 2008. Climate of the Arctic marine environment. Ecological Applications 18(2) Supplement:S3-S22.

Wu, Y., Peterson, I.K., Tang, C.C.L., Platt, T., Sathyendranath, S., and Fuentes-Yaco, C. 2007. The impact of sea ice on the initiation of the spring bloom on the Newfoundland and Labrador Shelves. Journal of Plankton Research 29(6):509-514. 